\title{
Failure to Discharge
}

National Cancer Institute

\section{Source}

National Cancer Institute. Failure to Discharge. NCI Thesaurus. Code C63181.

Problem associated with the failure of a battery or other charge storage device to appropriately discharge as intended. Does not apply to defibrillation. 